\title{
RANCANGAN EVALUASI PROGRAM PERKULIAHAN PENGETAHUAN \\ LINGKUNGAN BERMUATAN SUSTAINABLE DEVELOPMENT (SD) UNTUK MENINGKATKAN ECOLOGY INTELLIGENCE CALON GURU BIOLOGI
}

\author{
Oleh \\ Armansyah Putra \\ Program Doktor Pendidikan IPA Universitas Pendidikan Indonesia \\ Dosen Universitas Samawa, Sumbawa Besar \\ email : arman091088@gmail.com
}

\begin{abstract}
Abstrak
Evaluasi program bertujuan untuk melihat apakah program yang dirancang, dilaksanakan, bermanfaat bagi pihak-pihak yang terlibat dalam program. Pada pelaksanaannya evaluasi program bertujuan untuk menggali informasi sebanyak mungkin untuk mendapatkan gambaran rancangan dan pelaksanaan program. Hasil Evaluasi tersebut kemudian digunakan bagi pihak yang berkepentingan untuk mengambil keputusan. Setiap evaluator mempunyai tugas mengumpulkan seluruh informasi yang terkait dengan program. Dalam menjalankan tugasnya, evaluator dapat mengembangkan cara mengumpulkan informasi sesuai dengan paradigma dan pendekatan yang dianutnya, salah satunya adalah evaluasi Program perkuliahan yang merupakan suatu rencana pengajaran sebagai panduan bagi dosen dalam melaksanakan perkuliahan, agar perkuliahan dapat berjalan dengan baik. Terdapat banyak model evaluasi program yang digunakan para ahli. Salah satu model evaluasi yang tepat untuk program Perkuliahan Pengetahuan Lingkungan Bermuatan Sustainable Developmen untuk meningkatkan Ecology Intelligence adalah model Evaluasi CIPP (Context, Input, Process, Product), karena program ini belum diimplementasikan, serta model CIPP memiliki keunikan pada setiap tipe evaluasi terkait pada perangkat pengambil keputusan (decision) yang menyangkut perencanaan dan operasional sebuah program.
\end{abstract}

Kata Kunci : Evaluasi Program, Sustainable Development, Ecology Intelligence

\section{A. Pendahuluan}

Evaluasi program merupakan suatu proses, yang secara eksplisit evaluasi mengacu pada pencapaian tujuan sedangkan secara implisit evaluasi harus membandingkan apa yang telah dicapai dari program dengan apa yang seharusnya dicapai berdasarkan kriteria yang telah ditetapkan. Pada konteks pelaksanan program, kriteria yang dimaksud adalah kriteria keberhasilan pelaksanaan dan hal yang dinilai adalah hasil atau prosesnya itu sendiri dalam rangka pengambilan keputusan. Shadish (1998) mengemukakan bahwa teori evaluasi akan menuntun kita untuk lebih jauh mengembangkan tentang evaluasi dan sebagai basis pengetahuan tentang profesi kita. Stufflebeam, juga menekankan pentingnya mempelajari teori evaluasi dan 
pendekatannya. Ia menulis, "The study of alternative evaluation approaches is important for professionalizing program evaluation and for its scientific advancement and operation".

Banyak orang memandang bahwa evaluasi adalah sinonim dari professional judgment, judgment terhadap mutu program berdasarkan pendapat ahli. Pada lingkup sekolah evaluasi dipandang sebagai proses membandingkan antara data kinerja siswa dengan tujuan dan capaian pembelajaran yang diharapkan, dari sana evaluasi bisa dipandang sebagai sinonim dari controlled experimental research. Pandangan tersebut membangun hubungan kausal antara program dan hasil. Beberapa fokus menyoroti pentingnya permintaan naturalistik atau dorongan akan nilai pluralisme yang perlu diakui, ditampung dan dijaga. Fokus lain juga menyoroti pentingnya "social equity", berpendapat bahwa orang-orang yang terlibat pada entitas evaluasi harus memainkan peranan yang penting, bahkan peran utama, peran untuk menetapkan arah tentang studi evaluasi yang diambil dan bagaimana melakukannya. (Fitzpatrick, et al. 2012)

Program perkuliahan merupakan suatu rencana pengajaran sebagai panduan bagi dosen dalam melaksanakan perkuliahan, dimana supaya perkuliahan dapat berjalan dengan baik. Program perkuliahan yang dibuat oleh dosen tidak selamanya dapat dilaksanakan dengan baik. Sehubungan dengan hal tersebut, maka supaya program perkuliahan yang telah dibuat tidak memiliki kelemahan yang terjadi pada program perkuliahan berikutnya, maka perlu dilakukan evaluasi program perkuliahan, khususnya untuk mata kuliah pengetahuan lingkungan karena hal ini merupakan salah satu faktor penting untuk mencapai tujuan pendidikan yang baik. Dalam proses tersebut faktor efektivitas perkuliahan, faktor evaluasi baik terhadap proses maupun hasil perkuliahan juga perlu mendapat perhatian.

Sebuah program bukan hanya kegiatan tunggal yang dapat diselesaikan dalam waktu singkat, tetapi merupakan kegiatan yang berkesinambungan karena melaksanakan suatu kebijakan. Oleh karena itu, sebuah program dapat berlangsung dalam kurun waktu relatif lama. Program adalah suatu unit kegiatan atau kesatuan kegiatan yang berbentuk sistem, yaitu rangkaian kegiatan yang dilakukan bukan hanya satu kali tetapi berkesinambungan (Arikunto, 2014). Berdasarkan makna tersebut, program perkuliahan mahasiswa dapat diartikan sebagai rencana berupa serangkaian kegiatan yang akan dilaksanakan dalam rangka untuk mencapai suatu tujuan yang telah ditetapkan. Perencanaan program perkuliahan mahasiswa oleh dosen akan membantu pelaksanaan kegiatan itu menjadi terarah, efektif dan efisien, 
sehingga dapat meningkatkan baik kualitas maupun kuantitatas lulusan suatu perguruan tinggi. Sebaliknya bila kegiatan itu dilaksanakan tanpa terprogram akan menurunkan produktivitas kelulusan suatu perguruan tinggi.

Selama ini perkuliahan pengetahuan lingkungan belum sepenuhnya bermuatan Sustainable Development yang dapat meningkatkan Ecology Intelligence calon guru biologi. Sehubungan dengan hal tersebut maka evaluasi program perkuliahan yang akan dilakukan adalah terhadap perkuliahan yang bermuatan Sustainable Development agar dapat meningkatkan Ecology Intelligence calon guru biologi pada mata kuliah pengetahuan lingkungan.

\section{B. Tujuan Program}

Berdasarkan latar belakang permasalahan di atas, maka tujuan dari evaluasi program ini adalah untuk melihat pelaksanaan, efektivitas, faktor-faktor kendala, dan upaya mengatasi kendala serta hasil yang dicapai mahasiswa dalam program perkuliahan pengetahuan lingkungan bermuatan Sustainable Development.

\section{Pentingnya Program di Evaluasi}

Program ini penting untuk dievaluasi sebagai wahana peningkatan kualitas pelaksanaan perkuliahan mahasiswa yang dilaksanakan setiap semesternya, perkuliahan yang berkualitas tentunya akan sangat berdampak terhadap kepercayaan masyarakat untuk memasukan anaknya ke program studi yang berkualitas. Hasil dari evaluasi program yang dilakukan sebagai bahan evaluasi untuk perbaikan kualitas pelaksanaan perkuliahan untuk semester-semester berikutnya.

\section{Tujuan Evaluasi}

Evaluasi program perkuliahan bermuatan Sustainable Development bertujuan untuk:

1. Memperoleh informasi mendalam mengenai hasil perkuliahan pengetahuan lingkungan bermuatan Sustainable Development.

2. Meningkatkan kualitas perkuliahan, termasuk komponen-komponennya.

3. Memperbaiki komponen program perkuliahan yang dirasa kurang sesuai dengan tujuan perkuliahan.

4. Sebagai pedoman dalam pelaksanaan kegiatan Program Perkuliahan pengetahuan lingkungan bermuatan Sustainable Development, hal ini dilakukan agar kegiatan yang akan dilaksanakan lebih terencana dan terstruktur.

5. Membantu mahasiswa agar dapat memenuhi kebutuhan dan memecahkan masalah yang dihadapi. 


\section{E. Manfaat Evaluasi}

Evaluasi program perkuliahan bermuatan Sustainable Development bermanfaat untuk:

1. Bagi mahasiswa dapat mengetahui tingkat pencapaian tujuan perkuliahan secara mendetail.

2. Bagi dosen dapat mendeteksi mahasiswa yang telah dan belum menguasai tujuan perkuliahan, ketepatan materi yang diajarkan, ketepatan metode yang digunakan.

3. Bagi lembaga/prodi, hasil program perkuliahan dapat mencerminkan kualitas program studi.

\section{F. Studi Literatur}

\section{a. Sustainable Development (SD)}

Pembangunan berkelanjutan yang berwawasan lingkungan hidup yang kita pergunakan disini adalah merupakan terjemahan dari "suistainable development" yang sangat populer dipergunakan di negara-negara Barat. Istilah Pembangunan Berkelanjutan" di indonesia secara resmi dipergunakan dalam Tap MPR No. IV /MPR/1999 tentang GBHN, sedangkan istilah Pembangunan berkelanjutan yang berwawasan Lingkungan Hidup" digunakan dalam UU No. 23 Tahun 1997 tentang Pengelolaan Lingkungan Hidup.

Pembangunan berkelanjutan menggambarkan suatu komitmen untuk memajukan kesejahteraan manusia, dengan batasan bahwa perkembangan ini perlu terjadi dalam batasan-batasan ekologi biosfir. Pembangunan berkelanjutan memiliki daya tarik yang luas dan spesifisitas yang kecil, tetapi beberapa gabungan pembangunan dan lingkungan dan juga kesetaraan ditemukan dalam banyak usaha untuk menggambarkannya. (Rajalaksmi, 2016) 


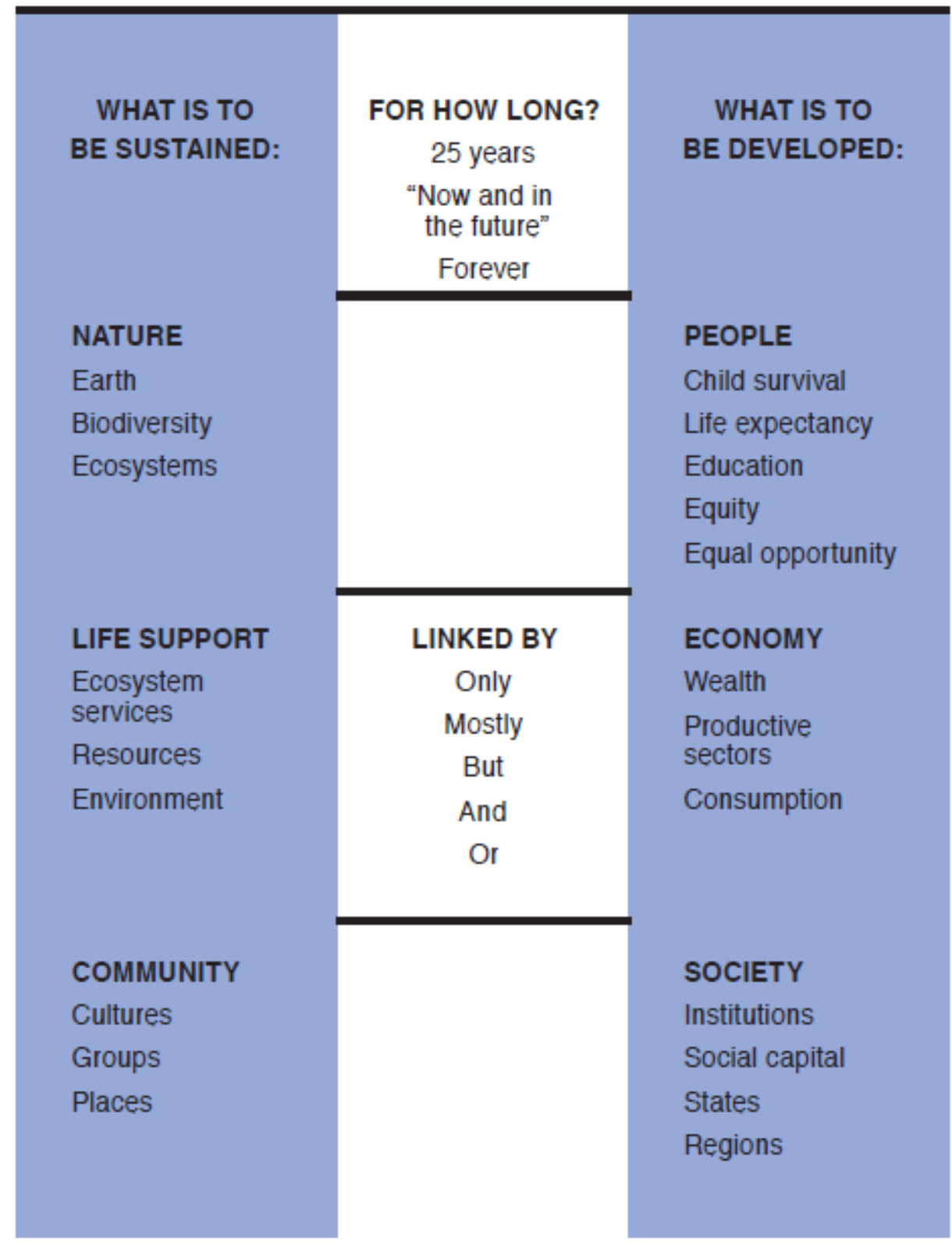

Gambar 1. Definition Sustainable DevelopmentNational Research Council, Policy Division, Board on Sustainable Development, Our Common Journey: A Transition Toward Sustainability (Washington, DC: National Academy Press, 1999) 


\section{b. Ecology Intelligence (EI)}

Alam itu cerdas, manusia adalah bagian dari alam dan sebaliknya, Kecerdasan tersebut pada manusia adalah persepsi bagaimana manusia mengerti dan menilai lingkungan melalui penginderaan dan dikoordinasikan di dalam syaraf pusat yang lebih tinggi (otak) sehingga manusia dapat mengenali dan menilai obyek-obyek. Tingkat pengenalan oleh penginderaan tersebut dapat dikatakan sebagai suatu kepekaan. (Akkuzu, 2016)

Kepekaan terhadap suatu khasanah obyek dapat dikenali dari respon yang dapat terjadi akibat stimulus yang diterima. Tingkat kepekaan terhadap obyek tersebut disebut sensitivitas. Hal ini juga seperti yang dikemukakan oleh Silverman, bahwa kepekaan emosional yang alami disebut sensitivitas, dan bahkan cenderung disebut bakat atau gifteddan dapat mencirikan sebagai hal yang positif. Dalam pernyataan tersebut dapat dimaksud bahwa sensitivitas adalah bakat kepekaan individu baik pada dimensi emosional, daya pikir, maupun kemampuan secara fisik.

Apabila dikaitkan dengan keberadaan khasanah-khasanah ekologis, maka bakat kepekaan individu akan berorientasi pada asas-asas proses ke-alami-an atau natural. Khasanah ekologis yang merupakan interaksi hubungan timbal balik antar komponen penyusun biotik dan abiotik, sesuai konsep dasarnya dapat meliputi yaitu produktivitas, populasi, simbiose, rantai makanan, siklus unsur hara, dan hukum energi.

Kecerdasan sebagai landasan dalam pencapaian tingkat sensitivitas, di dalam teori triachic tentang kecerdasan manusia oleh Stenberg terdiri dari tiga sub-teori, yaitu 1) kecerdasan komponensial 2) kecerdasan pengalaman, dan 3) kecerdasan kontekstual. Kecerdasan komponensial (Componential intelligence) merupakan 
mekanisme mental internal individu yang bertanggungjawab terhadap perilaku, termasuk proses pengambilan keputusan, kinerja, dan pemenuhan pengetahuan. Kecerdasan pengalaman (Experiential intelligence), mencakup kemampuan untuk mengerjakan sesuatu yang baru, kemampuan memproses informasi secara cepat. Sedangkan kecerdasan kontekstual (Contextual intelligence) mencakup kemampuan untuk beradaptasi pada suatu lingkungan yang baru, dan kemampuan dalam penyesuaian lingkungan.

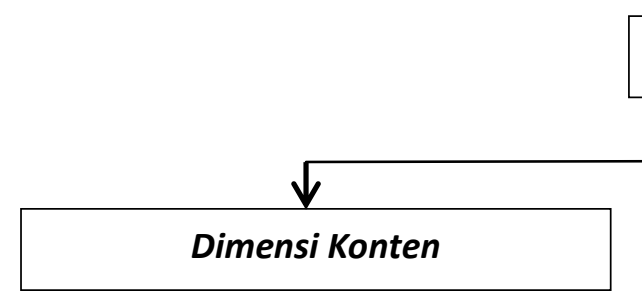

1. Pengetahuan tentang prinsip dan proses ekologi yang berhubungan dengan biodiversitas

1. Faktor ekologi yang mempengaruhi biodiversitas

2. Nilai-nilai ekologi dari biodiversitas

2. Pengetahuan tentang permasalahan yang berhubungan dengan biodiversitas
a. Nilai Biodiversitas untuk manusia
b. Cara mengatasi berkurangnya biodiversitas

3. Pengetahuan tentang strategi dan langkah kongkrit penyelamatan biodiversitas

a. Penggunaan strategi untuk investigasi permasalahan

b. Aksi yang sesuai untuk mencegah atau solusi terhadap permasalahan biodiversitas

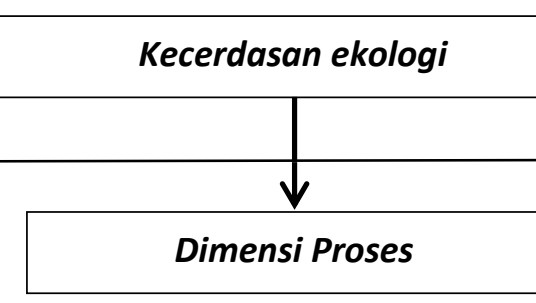

1. Mengidentifikasi problem

2. Mengkoleksi data dan mengolah informasi

3. Menemukan informasi yang layak dan mendukung

4. Membuat dan menginterpretasi grafik dan tabel

5. Menganalisis data dan menginterpretasikannya

6. Memprediksi outcome nya

7. Merumuskan solusi dan pemecahan masalah

\section{Dimensi Sikap}

1. Kepekaan dan nilai positif terhadap pencegahan
a. Kepekaan
b. Nilai-nilai

2. Belief tentang personal dan masyarakat yang berhubungan dengan biodiversitas

a. Harapan atau keputusan

b. Tanggung jawab pribadi

c. Tanggung jawab sosial 


\section{Bagan : Alur Ecology intelligence}

\section{G. Model Evaluasi yang digunakan dalam program}

Evaluasi merupakan Proses penentuan informasi yang diperlukan, pengumpulan serta penggunaan informasi tersebut untuk melakukan pertimbangan sebelum membuat keputusan (Firman, 2007). Terkait program perkuliahan pengetahuan lingkungan bermuatan Sustainable Development ini, melibatkan banyak tahapan pekerjaan, pengelola memerlukan dukungan informasi evaluatif berorientasi manajemen yang handal. Terdapat banyak model evaluasi program yang digunakan para ahli. Salah satu model evaluasi yang tepat untuk program ini adalah model CIPP (Context, Input, Process, Product) yang diperkenalkan dan dikembangkan oleh Stufflebeam (1971), karena program ini belum diimplementasikan, serta model CIPP memiliki keunikan pada setiap tipe evaluasi terkait pada perangkat pengambil keputusan (decision) yang menyangkut perencanaan dan operasional sebuah program. Keunggulan model CIPP memberikan suatu format evaluasi yang menyeluruh pada setiap tahapan evaluasi yaitu tahap konteks, masukan, proses, dan produk.

\section{H. Evaluasi Program Perkuliahan}

Sekian banyak pendekatan evaluasi yang telah muncul sejak Tahun 1960 berkisar dari model yang komprehensif dan tindakan yang akan diambil. Beberapa penulis memilih pendekatan komprehensif untuk menilai program, sementara penulis lain memandang evaluasi sebagai proses mengidentifikasi dan mengumpulkan informasi untuk membantu para pembuat keputusan. (Fitzpatrick, et al. 2012). Ada berbagai macam jenis evaluasi program yang dikenal dalam bidang pengetahuan, di mana salah satunya adalah evaluasi program yang banyak digunakan dalam kajian kependidikan. Evaluasi program mengalami perkembangan yang berarti sejak Ralph Tyler, Scriven, John B. Owen, Lee Cronbach, Daniel Stufflebeam, Marvin Alkin, Malcolm Provus, R. Brinkerhoff dan lainnya (Soenarto Sapoetro, 1995). Banyaknya kajian evaluasi program membawa implikasi semakin banyaknya model evaluasi, yang berbeda cara dan penyajiannya, namun apabila ditelusuri semua model bermuara kepada satu tujuan yang sama yaitu menyediakan informasi dalam kerangka keputusan bagi pengambil kebijakan. Pada bidang pendidikan evaluasi dapat dikelompokkan ke dalam tiga cakupan yaitu evaluasi pembelajaran, evaluasi program, dan evaluasi sistem, yang dapat dilakukan untuk peserta didik, lembaga, dan program pendidikan baik formal ataupun nonformal. 
Definisi evaluasi dari berbagai pendapat, diantaranya yang dikemukan (Kufman and Thomas, 1980) menyatakan bahwa evaluasi adalah proses yang digunakan untuk menilai. Hal senada dikemukakan oleh (Djaali, et al, 2000) mendefinisikan evaluasi dapat diartikan sebagai proses menilai sesuatu berdasarkan kriteria atau standar objektif yang dievaluasi. Sedangkan (Sanders, 1994) sebagai ketua The Joint Committee on Standars for Educational Evaluation mendefinisikan evaluasi sebagai kegiatan investigasi yang sistimatis tentang kebenaran atau keberhasilan suatu tujuan.

Pengertian evaluasi program berbeda-beda sesuai dengan pengertian evaluasi yang bervariatif yang dikemukakan oleh para pakar evaluasi. Stufflebeam (1986) mengemukakan bahwa evaluasi adalah proses memperoleh dan menyajikan informasi yang berguna untuk mempertimbangkan alternatif-alternatif pengambilan keputusan. Pendapat lain dari Suharsimi (1999) mengemukakan bahwa "Evaluasi program adalah suatu rangkaian kegiatan yang dilakukan dengan sengaja untuk melihat keberhasilan program". Sehingga mengandung beberapa pengertian tentang program itu sendiri, diantaranya adalah rencana dan kegiatan yang direncanakan dengan seksama. Dengan demikian melakukan evaluasi program merupakan kegiatan yang bertujuan untuk mengetahui seberapa tinggi tingkat keberhasilan kegiatan yang telah direncanakan.

Model pendekatan didalam evaluasi program ada berbagai macam yang dikemukakan oleh para ahli, dimana pada dasarnya semua metode dapat diterapkan dalam setiap kegiatan evaluasi program, meskipun ada perbedaan. Perbedaan terletak pada titik fokus permasalahan, konteks dari permasalahan yang akan dievaluasi, jenis keputusan yang akan diambil, dan tahapan program yang akan dievaluasi. Beberapa jenis pendekatan tersebut adalah : pendekatan untuk menilai kualitas keseluruhan, pendekatan yang berorientasikan pada karakteristik program, pendekatan yang berorientasi pada keputusan, pendekatan yang berorientasi pada partisipan. Keseluruhan pendekatan tersebut merepresentasikan dalam membangun rencana untuk mengatur rencana evaluasi khususnya di sekolah. (Fitzpatrick, et al. 2012)

\section{Metode Evaluasi Program}

\section{Metode evaluasi}

Program perkuliahan pengetahuan lingkungan bermuatan Sustainable Development ini akan dievaluasi menggunakan model evaluasi CIPP (context, input, proses, dan produk). Turunan dari model CIPP ini adalah metode yang 
digunakan dalam evaluasi program yaitu metode mixed methods (Creswell, 2012) dengan unjuk kerja baik dengan menggunakan analisis secara kuantitatif maupun kualitatif. Desain evaluasi program yang akan digunakan adalah desain penelitian berupa desain embedded. Ciri utama dari embedded design (desain sisipan) adalah desain metode campuran dimana satu set data memberikan dukungan pada set data lain yang menjadi peran dalam kajian utamanya. Pada desain ini data kuantitatif akan disisipkan (embedding) untuk keperluan pengembangan perlakuan, untuk menguji proses intervensi atau untuk menindaklanjuti hasil-hasil dari program perkuliahan.

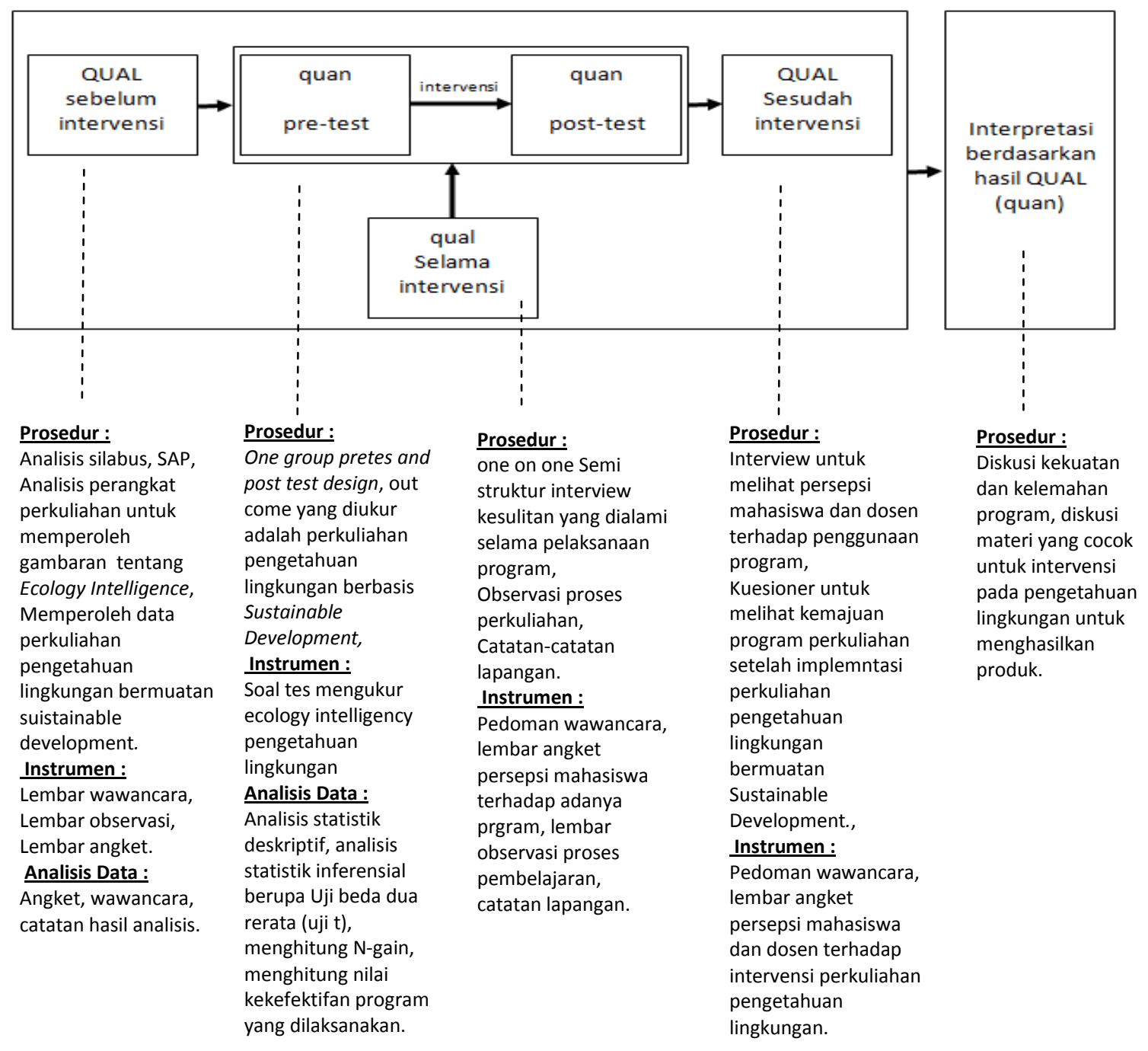

\section{Kriteria atau variabel yang dievaluasi}

Adapun beberapa variabel yang dievaluasi menggunakan CIPP ini ialah:

1. Context, mencakup evaluasi kemampuan awal mahasiswa, permasalahanpermasalahan yang dihadapi mahasiswa saat perkuliahan, penyusunan program perkuliahan, kelemahan-kelemahan dalam perkuliahan, media dan alat 
perkuliahan, bahan perkuliahan, asesmen perkuliahan, angket evaluasi diri mahasiswa mengenai penyelenggaraan program perkuliahan bermuatan Sustainable Development

2. Input, mencakup evaluasi profil mahasiswa, profil pengajar dan profil fasilitas yang dimiliki oleh lembaga yang menerapkan program. Evaluasi profil mahasiswa mencakup kapasistas belajar. Evaluasi profil dosen meliputi informasi tingkat pendidikan dosen, pengalaman mengajar dosen, sikap inovasi dan kreasi dosen, budaya kerja kampus dan kesedian waktu yang dimiliki oleh dosen. Evaluasi profil fasilitas yang dimiliki oleh lembaga meliputi evaluasi buku pegangan yang digunakan, evaluasi teknologi administrasi, evaluasi ruangan perkuliahan, evaluasi perpustakaan, evaluasi laboratorium biologi.

3. Proses, berkenaan dengan kajian seberapa jauh pelaksanaan perkuliahan yang bermuatan Sustainable Development, evaluasi profesional dosen, dan evaluasi tingkat kehadiran mahasiswa dan dosen.

4. Product/output, mencakup tingkat keberhasilan mahasiswa mengalami peningkatan dalam hasil perkulihahan, tingkat kepuasan mahasiswa selama pembelajaran, feedback dari mahasiswa dan orang tua mahasiswa, serta feedback dosen terhadap program yang telah dilalui.

\section{Diagram Alur Proses evaluasi}

Prosedur umum untuk pelaksanaan evaluasi ini mengkuti langkah-langkah berikut:

1. Menentukan tujuan evaluasi: Need Assesmen, fokus evaluasi, alat dalam pengumpulan data.

2. Menyusun desain evaluasi yang kredibel: menentukan target dan sasaran evaluasi program.

3. Mendiskusikan rencana evaluasi; objek evaluasi, penyandang dana, keterlibatan ahli evaluasi yang berkompeten.

4. Menyusun instrumen evaluasi berupa: lembar observasi dan panduan wawancara, angket, dan test.

5. Melaksanakan evaluasi program perkuliahan berbasis Sustainable Development

6. Menyusun kriteria penilaian

7. Mengumpulkan data atau informasi terkait dengan pelaksanaan kegiatan. 
8. Mengolah data temuan atau data utama dan menganalisis dan Interpretasi Data.

9. Penarikan Kesimpulan dan pengajuan rekomendasi

Tahapan pelaksanaan evaluasi program, disajikan pada gambar berikut ini:

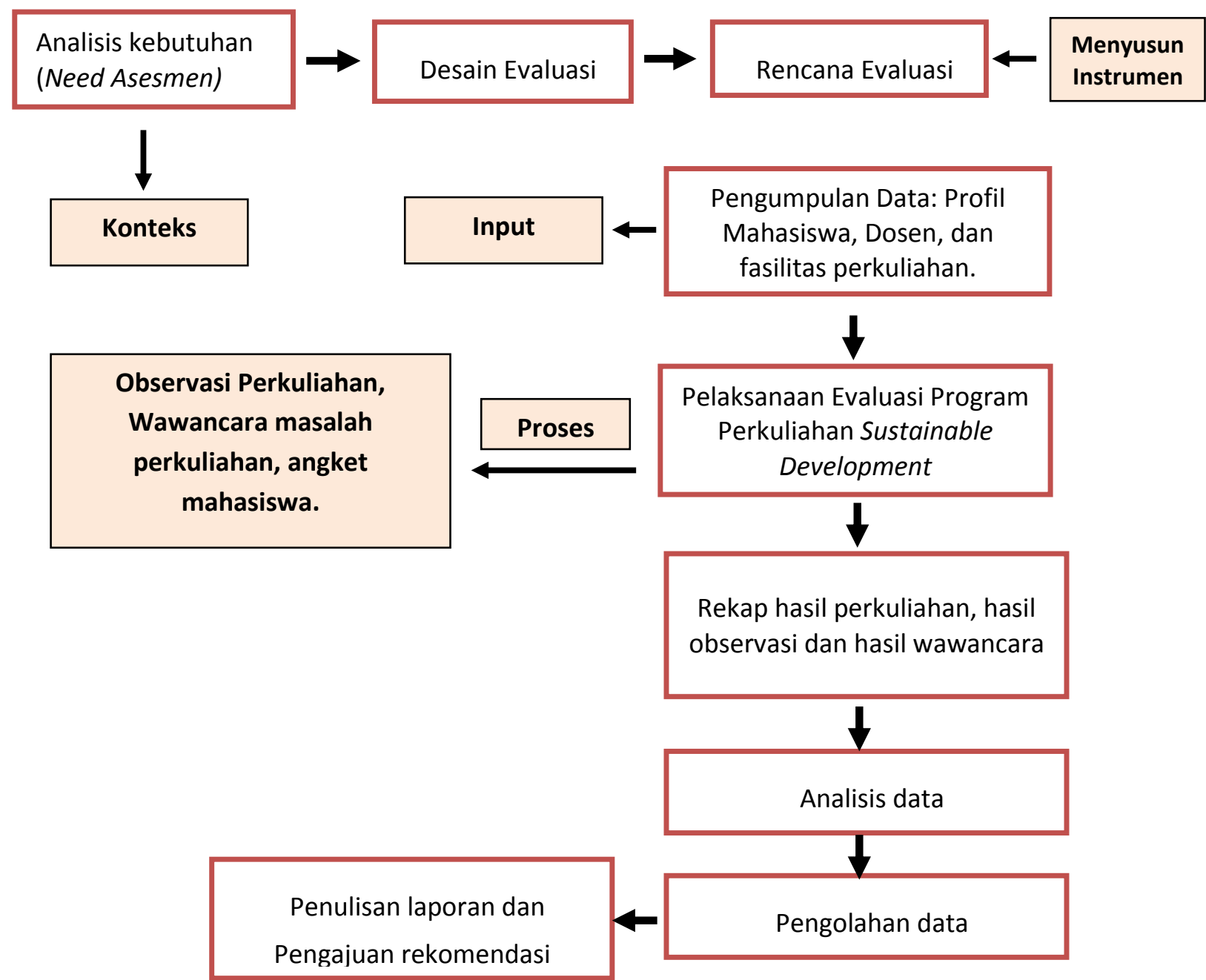

Gambar 1. Diagram alur proses evaluasi program perkuliahan bermuatan Sustainable Development

\section{Alat pengumpulan data}

Beberapa metode pengumpulan data yang akan dilakukan antara lain:

\section{Analisis Dokumen}

Analisis dokumen ini berupa analisis terhadap perangkat perkuliahan, seperti Silabus dan Satuan Acara Perkuliahan (SAP) yang dibuat oleh dosen pengampu mata kuliah, Buku ajar atau modul perkuliahan. Analisis perangkat perkuliahan ini dilakukan untuk menyesuaikan antara perangkat perkuliahan 
yang dibuat oleh dosen pengampu dengan perangkat perkuliahan pada proses perkuliahan.

\section{Observasi Perkuliahan}

Langkah obesrvasi yang dilakukan menyusun dan menyiapkan instrument yang terdiri dari lembar observasi kemampuan mahasiswa, lembar observasi pelaksanaan perkuliahan, Lembar analisis Silabus dan Satuan Acuan Perkuliahan (SAP), dan angket siswa.

\section{Angket Mahasiswa}

Instrumen yang digunakan dalam evaluasi Program Perkuliahan Pengetahuan Lingkungan Bermuatan Sustainable Development ini adalah berupa angket sebagai alat ukur untuk mengetahui ke dalam mahasiswa. Bentuk butir-butir angket disusun dalam pernyataan yang akan dijawab oleh mahasiswa.

Lembar angket yang digunakan berupa daftar pertanyaan yang dibuat dalam bentuk daftar chek list yang harus diisi oleh mahasiswa. Angket ini terdiri atas pertanyaan dengan pilihan "Sangat Setuju (SS)", "Setuju (S)", "Tidak Setuju (TS)", "Sangat Tidak Setuju (STS)" yang digunakan untuk memperoleh tanggapan mahasiswa mengenai proses perkuliahan sebagai tambahan data evaluasi program.

\section{Tes Ecology Intelligency}

Bentuk tes yang digunakan dalam penelitian ini adalah pilihan obyektif. Pilihan obyektif teridiri dari dua macam, yaitu pilihan sederhana (simple multiple-choice) dengan empat alternatif jawaban (A, B, C, dan D) dan pilihan kompleks (complex multiple-choice) dengan jawaban alasan mengapa memilih jawaban tersebut atau kalimat terbuka yang menuntut jawaban berupa penjelasan (Hadinugraha, 2012).

5. Wawancara

Salah satu metode yang digunakan untuk menggali pandangan dosen, adalah metode wawancara. Instrumen ini berupa wawancara yang memuat pertanyaan tentang tanggapan pandangan dan tanggapan dosen berkenaan dengan perkuliahan Pengetahuan Lingkungan. Wawancara ini dilakukan setelah:

a. Melakukan analisa terhadap data yang didapat dari para mahasiswa, kemudian memberikan perkuliahan di kelas sesuai dengan kebutuhan mahasiswa. 
b. Setelah menganalisa data yang didapat dari mahasiswa, dosen menetapkan pemberian perkuliahan kelompok dalam bentuk perkuliahan informasi mengenai standar nilai kelulusan tahun lalu dan standar nilai kelulusan yang harus dicapai mahasiswa pada semester ini.

c. Selain itu, dosen memberikan informasi cara-cara belajar yang efektif untuk meningkatkkan Ecology Intelligency mahasiswa.

\section{Teknik pengolahan dan analisis data}

Setelah proses pengambilan data selesai, maka diperoleh jumlah data kuantitatif dan kualitatif. Pengolahan dan analisis data berpedoman pada data yang terkumpul. Data kuantitatif berupa hasil analisis perangkat perkuliahan berupa silabus, SAP, buku ajar dan modul peerkuliahan, observasi perkuliahan, dan jawaban angket mahasiswa dengan uji statistik. Data kualitatif berupa hasil wawancara dengan dosen pengampu mata kuliah dan mahasiswa, dan studi dokumentasi dianalisis secara deskriptif untuk mengetahui kecenderungan data atau temuan yang akan digunakan dalam menarik kesimpulan. Data yang diperoleh diolah sesuai dengan langkah-langkah berikut:

- Analisis dokumen dan observasi perkuliahan

Melakukan rekapitulasi data berdasarkan analisis perangkat perkuliahan dan observasi pelaksanaan perkuliahan. Menghitung presentase menggunakan rumus Purwanto (2009), yaitu:

$\mathrm{NP}=\mathrm{R} / \mathrm{M} \times 100 \%$

Keterangan:

$\mathrm{NP}=$ Nilai persen yang dicari atau diharapkan

$\mathrm{R}=$ Skor mentah yang diperoleh

$\mathrm{SM}=$ Skor maksimum ideal dari tes yang bersangkutan

Setelah hasil didapat, maka lakukan penafsiran. Penafsiran dilakukan berdasarkan kategori menurut Purwanto (2009) sebagai berikut:

Tabel. 1

Kategori Presentase Silabus dan SAP, Proses Perkuliahan

\begin{tabular}{|c|c|}
\hline Persentase & Predikat \\
\hline $86-100 \%$ & Sangat Baik \\
\hline $75-85 \%$ & Baik \\
\hline $60-75 \%$ & Cukup \\
\hline $55-59 \%$ & Kurang \\
\hline$\leq 54 \%$ & Kurang Sekali \\
\hline
\end{tabular}


- Analisis Angket

Angket yang digunakan diolah dengan cara menghitung jumlah mahasiswa yag menjawab "SS", "S", “TS", dan "STS" untuk setiap pernyataan pada angket. Langkah selanjutnya yaitu dnegan melakukan perhitungan persentase jawaban mahasiswa untuk setiap pernyataan dengan rumus sebagai berikut (Koentjaraningrat, 1990):

Persentase tanggapan mahasiswa $=\quad$ Jumlah mahasiswa yang menjawab pada setiap item $\times 100 \%$ Jumlah seluruh mahasiswa

Hasil perhitungan selanjutnya diinterpretasi dengan cara membuat kategori untuk setiap kriteria berdasarkan table aturan Koentjaraningrat (1990) sebagai berikut:

Tabel. 2

Kategori untuk setiap kriteria

\begin{tabular}{|c|c|}
\hline Persentase & Predikat \\
\hline $0 \%$ & Tidak ada \\
\hline $1-25 \%$ & Sebagian kecil \\
\hline $26-49 \%$ & Hampir seluruhnya \\
\hline $50 \%$ & Separuhnya \\
\hline $51-75 \%$ & Sebagian besar \\
\hline $76-99 \%$ & Hampir seluruhnya \\
\hline $100 \%$ & Seluruhnya \\
\hline
\end{tabular}

- Triangulasi Data

Untuk memperoleh kebenaran, evaluasi ini menggunakan teknik Triangulasi. Menurut Patton, triangulasi data berarti membandingkan dan mengecek balik derajat kepercayaan suatu informasi yang diperoleh melalui waktu dan alat yang berbeda dalam metode kualitatif (Moleong, 1990). Triangulasi data dari penelitian ini diperoleh dengan melakukan cross-check informasi antara informan yang satu dengan yang lain. Adapun dari beberapa macam teknik triangulasi, maka pada penelitian ini yang akan digunakan adalah teknik triangulasi sumber.

Triangulasi sumber ini dapat dilakukan dengan beberapa jalan, yaitu :

a. Membandingkan data hasil pengamatan dengan hasil wawancara. 
b. Membandingkan apa yang dikatakan orang di depan umum dengan apa yang dikatakan secara pribadi.

c. Membandingkan apa yang dikatakan orang-orang tentang situasi penelitian dengan apa yang dikatakannya sepanjang waktu.

d. Membandingkan keadaan dan prespektif seseorang dengan berbagai pendapat dan pandangan orang, seperti rakyat biasa, orang yang berpendidikan menengah atau tinggi, orang berada, dan orang pemerintahan.

e. Membandingkan hasil wawancara dengan isi dokumen yang berkaitan.

Dari kelima jalan dalam proses triangulasi sumber tersebut, maka pada evaluasi ini akan digunakan jalan dengan membandingkan:

1. Hasil wawancara dengan hasil pengamatan,

2. Hasil wawancara dengan dokumen yang berkaitan (hasil ujian mahasiswa).

- Analisa Statistik

Untuk hasil angket dari mahasiswa, akan dilakukan analisis statistik deskriptif menggunakan software SPSS. Sementara, untuk mengetahui ada tidaknya perbedaan nilai mahasiswa antara kelas yang melakukan kegiatan Program Perkuliahan Pengetahuan Lingkungan Bermuatan Sustainable Development dengan yang tidak, akan dilakukan uji beda 2 sampel independent terhadap hasil ujian di pertengahan semester dan ujian akhir semester seluruh mahasiswa yang melakukan kegiatan Program Perkuliahan Pengetahuan Lingkungan.

\section{J. Simpulan}

Evaluasi merupakan Proses penentuan informasi yang diperlukan, pengumpulan serta penggunaan informasi tersebut untuk melakukan pertimbangan sebelum membuat keputusan. Evaluasi dapat digunakan untuk memeriksa tingkat keberhasilan program berkaitan dengan lingkungan program untuk suatu "judgement" apakah program diteruskan, ditunda, diperbaiki, dikembangkan, ditingkatkan, diterima, atau ditolak. Adapun untuk program perkuliahan mestinya tetap diteruskan dengan perbaikan pada bagian-bagian yang kurang, dikembangkan dan ditingkatkan.

Evaluasi program pembelajaran/perkuliahan merupakan pendekatan formal yang digunakan untuk menilai program pembelajaran, sehingga dapat dilakukan 
oleh dosen secara berkelanjutan yang hasilnya langsung dapat digunakan untuk melakukan perbaikan. Evaluasi tersebut bertujuan menemukan kekuatan dan kelemahan berbagai komponen pembelajaran. Hasil yang diperoleh segera dapat ditindak lanjuti sehingga kelemahan pembelajaran dapat diperbaiki dan kekuatan dapat dipertahankan

Salah satu model Evaluasi Program yang digunakan adalah CIPP yang melihat kepada empat dimensi yaitu dimensi Konteks, dimensi Input, dimensi Proses dan dimensi Produk, yang memiliki keunikan yaitu pada setiap tipe evaluasi terkait pada perangkat pengambi keputusan yang menyangkut perencanaan dan operasional sebuah program. Keunggulan model CIPP memberikan suatu format evaluasi yang komprehensif pada setiap tahapan evaluasi yaitu tahap konteks, masukan, proses, dan produk. Evaluasi konteks adalah upaya untuk menggambarkan dan merinci lingkungan, kebutuhan yang tidak terpenuhi, populasi dan sampel yang dilayani dan tujuan proyek. Evaluasi konteks dimulai dengan melakukan analisis konseptual dalam mengidentifikasikan dan merumuskan domain yang akan dinilai dan kemudian diikuti dengan analisis empiris tentang aspek-aspek yang dinilai: melalui survey, tes dan sebagainya. 


\section{DAFTAR PUSTAKA}

Akkuzu, A. 2016 .Towards a Profound Ecological Understanding: Statistical Attempts to Measure our Ecological Intelligence. International J. Soc. Sci. \& Education Vol.6 Issue

Arikunto, (1999). Dasar-dasar Evaluasi Pendidikan, Jakarta: PT. Bumi Aksara. (2014). Evaluasi Program Pendidikan: Pedoman teoritis praktis bagi mahasiswa dan praktisi pendidikan. Jakarta: Bumi Aksara.

Creswell, John W. (2012). Educational Research: Planning, Conducting, and Evaluating quantitative and qualitative research. $4^{\text {th }}$ ed. University of Nebrarka. Licoln

Dialii, Mulyono, Ramly. (2000). Pengukuran dalam Bidang Pendidikan. Jakarta: IKIP Jakarta

Firman Harry. (2007). Monitoring and Evaluation Strategy of Lesson Study Programme (Strategi Monitoring dan Evaluasi Program Lesson Study). Artikel yang dipresentasikan pada 1st International conference on Lesson Study, FPMIPA UPI,Bandung.

Fitzpatrick, J.L., Sanders, J.R., \& Worthen, R.B. (2012) Program Evaluation: Alternative Approaches and Practical Guidelines. New Jersey: Pearson Education.

Hadinugraha, Syam. (2012). Literasi Sains SMA Berdasarkan kerangka PISA pada Konten Pengetahuan Biologi. Universitas Pendidikan Indonesia

Kaufman, P. dan Thomas, S. (1980). Evaluating without fear. New York: New Viewpoints

Koenjoroningrat. (1990). Metode-metode Penelitian Masyarakat. Jakarta: Pustaka Jaya

Moleong. (1990). Metodologi Penelitian Kualitatif. Bandung: Remadja Karya

National Research Council.(1999), Policy Division, Board on Sustainable Development, Our Common Journey: A Transition toward Sustainability (Washington, DC: National Academy Press)

Purwanto. (2009). Evaluasi Hasil Belajar. Surakarta: Pustaka Belajar. 
Rajalaksmi. S. 2016. Sustainable development through environmental ethics. International Journal of Applied Research

Sanders, J. R \& Sullins, C. D. 2006. Evaluating School Program. $3^{\text {rd }}$ Ed. Thousand Daks: Corwin Press.

Shadish, W.R (1998). Evaluation theory is who we are. American Journal of evaluations, 19(1), 1-19.

Soenarto, Sapoetro. (1995). Evaluasi Diri Perguruan Tinggi. Bogor: Dirjen DIKTI

Stufflebeam, D. L. \& Shinkfield, A. J. (1988). Systematic evaluation. Bston: Kluwer Nijhoff. 